\title{
The Effects of Inositol-deficiency on the Chemical Composition of the Yeast Cell Wall
}

\author{
By D. M. POWER* AND S. W. CHALLINOR \\ Department of Biochemistry, University of Birmingham \\ (Accepted for publication I I September I968)
}

\begin{abstract}
SUMMARY
Growth of a strain of Saccharomyces cerevisiae in an inositol-deficient chemically defined medium resulted in marked changes in the composition of the cell wall. Organisms grown in the complete absence of inositol possessed a weakened cell wall which contained more glucan and hexosamine but less mannan, phosphorus and protein than normal walls. The amino acid contents of the two types of cell wall were quite different but no significant change occurred in either the amount or the fatty acid composition of cell wall lipid. Treatment with ethylenediamine facilitated the isolation of three fractions, $\mathrm{A}, \mathrm{B}$, and $\mathrm{C}$ from normal and from deficient cell walls. The mannan and protein content of fractions A were strikingly similar. Deficient fractions B and $\mathrm{C}$ however contained considerably less mannan and protein but more glucan and hexosamine than the corresponding normal fractions.
\end{abstract}

\section{INTRODUCTION}

The yeast cell wall is composed mainly of glucan, mannan, protein and lipid (Northcote \& Horne, 1952; Roelofsen, 1953). Several workers have also reported the presence of small amounts (I-3\%) of chitin (Roelofsen \& Hoette, I95I ; Houwink \& Kreger, 1953; Falcone \& Nickerson, 1956; Eddy, 1958) but Korn \& Northcote (1960) estimated that not more than $9 \%$ of the cell wall glucosamine of bakers' yeast could be present as chitin. Although its chemical composition is well established, comparatively little is known about the fine-structure of the yeast cell wall. However, the fundamental importance of polysaccharide-protein complexes has been demonstrated (Falcone \& Nickerson, 1956; Kessler \& Nickerson, 1959; Eddy, 1958; Korn \& Northcote, 1960).

Inositol-deficiency results in various morphological changes in Saccharomyces cerevisiae w.s. including the formation of a cell wall markedly different in appearance under the electron microscope from that of the normal yeast (Challinor, Daniels \& Hall, 1958). This finding prompted a study of the structure of the cell walls and preliminary investigations (Challinor, Power \& Tonge, 1964) revealed changes in the chemical composition. In the present work, cell walls were fractionated by using ethylenediamine (Korn \& Northcote, 1960) and the isolated polysaccharide-protein complexes analysed.

* Present address: Department of Chemistry and Applied Chemistry, University of Salford. 


\section{METHODS}

Saccharomyces cerevisiae w.s. isolated from a top fermentation brewery pitching yeast was grown in chemically defined medium containing per $100 \mathrm{ml}$.: glucose, $6 \mathrm{~g}$., $\mathrm{KH}_{2} \mathrm{PO}_{4}, 0.2$ g., $\left(\mathrm{NH}_{4}\right)_{2} \mathrm{HPO}_{4}, 0.237$ g., $\mathrm{MgSO}_{4} .7 \mathrm{H}_{2} \mathrm{O}, 0 . \mathrm{I}$ g., $\mathrm{CH}_{3} \mathrm{CO}_{2} \mathrm{Na}_{3} \mathrm{H}_{2} \mathrm{O}$, $0.5 \mathrm{~g}$., $\mathrm{CaCl}_{2} .6 \mathrm{H}_{2} \mathrm{O}, 25 \mathrm{mg}$., $\mathrm{MnSO}_{4} .4 \mathrm{H}_{2} \mathrm{O}, \mathrm{I} \mathrm{mg}$., $\mathrm{KI}$, Io $\mu \mathrm{g}$., trace elements, O. I ml. (Emery, McLeod \& Robinson, 1946), calcium-D-pantothenate, $240 \mu \mathrm{g}$., thiamine hydrochloride, $200 \mu \mathrm{g}$., nicotinic acid, $200 \mu \mathrm{g}$., pyridoxine hydrochloride, $250 \mu \mathrm{g}$., D-biotin, $0.22 \mu \mathrm{g}$, inositol, I mg. The medium was adjusted to $\mathrm{pH} 5.5$. This medium, termed 'complete medium', supported maximum yeast growth. Inositoldeficient medium contained no inositol. Yeasts grown in these media and cell walls prepared from them are referred to as 'normal' and 'deficient' respectively. Stock cultures were maintained on complete medium solidified with agar ( 2 g./100 ml.).

Cultures for cell wall preparation were grown in 2.51. bottles (Glaxo pattern) containing $300 \mathrm{ml}$. of medium inoculated with I ml. of a well washed $(\times 3)$ suspension containing Io $\mu \mathrm{g}$. dry weight of yeast $/ \mathrm{ml}$. obtained from a $24 \mathrm{hr}$ complete medium liquid culture grown at $30^{\circ}$. After incubation at $30^{\circ}$ for $96 \mathrm{hr}$ for normal yeast or $\mathrm{I} 20 \mathrm{hr}$ for deficient yeast, the cells were harvested by centrifugation at $1000 \mathrm{~g}$ for Io min. The cells were then washed twice in saline and once in distilled water. Yields were dry wt equiv. $2 \mathrm{mg}$. normal yeast and I $\mathrm{mg}$. deficient yeast $/ \mathrm{ml}$.

\section{Preparation of cell walls}

A thick yeast suspension was prepared in distilled water (approx. $40 \mathrm{mg} . / \mathrm{ml}$. dry wt). A portion ( $5 \mathrm{ml}$.) was delivered into a Mickle cell (capacity $20 \mathrm{ml}$.) and Ballotini beads ( $\mathrm{mm}$., Chance Ltd.) were then added to a total volume of $15 \mathrm{ml}$. Cells were then sealed with polythene caps and vibrated at mains frequency in a Mickle disintegrator. The deficient yeast required $30 \mathrm{~min}$. for complete disintegration as judged by microscopic examination. Normal yeast, however, required shaking for at least $\mathrm{I}$ hr. A metal cage containing solid carbon dioxide supported directly above the vibrating cells maintained their temperature just above freezing. The glass beads were separated from cell contents by filtration through a fine network of glass-wool. The beads and glasswool were thoroughly washed with distilled water until the washings became clear. Centrifugation at $1500 \mathrm{~g}$ for Io min. at $4^{\circ}$ (Northcote \& Horne, 1952) resulted in sedimentation of the walls while other debris remained in suspension. The supernatant fluid was discarded, cell walls resuspended in distilled water and the process repeated. At least 50 washings were required before centrifugation produced a perfectly clear supernatant fluid. The cell walls were freeze-dried and stored in vacuo over phosphorus pentoxide at room temperature.

\section{Fractionation of cell walls}

Cell walls ( $\mathrm{I}$ g.) were incubated for 3 days at $37^{\circ}$ with anhydrous ethylenediamine $(250 \mathrm{ml}$.) and fractions isolated as described by Korn \& Northcote (1960).

\section{(a) Carbohydrate analyses}

\section{Analysis of cell walls and fractions}

Total carbohydrate was determined using the anthrone method (Chung \& Nickerson, 1954). 
Glucose. Samples (Io mg.) were stood at room temperature with concentrated sulphuric acid $(0.2 \mathrm{ml}$.) until dissolved. Water $(2 \mathrm{ml}$.) was then added, the tube sealed and heated at $95^{\circ}$ for $6 \mathrm{hr}$. The acid was neutralized with barium carbonate and the precipitated barium sulphate removed by centrifugation. The residue was washed three times with water and the supernatant and washings combined. The solution was then passed down a $9 \times 1 \mathrm{~cm}$. column of Amberlite I.R. I 20 resin to remove barium ions completely. The eluate was adjusted to $\mathrm{pH} 7$ and diluted to $100 \mathrm{ml}$. Glucose was determined by enzymic assay with glucose oxidase (The Boehringer Corporation (London) Ltd.). Maximum glucose liberation occurred after $6 \mathrm{hr}$ hydrolysis.

Mannose. The mannose content was obtained by subtracting the value obtained for glucose by glucose oxidase from that obtained by the anthrone method for total hexose (expressed as glucose). This value, mannan content expressed as glucose, was converted to a true mannose reading by reference to a standard mannose curve determined by the anthrone method.

Amino sugars. Samples (5-10 mg.) were hydrolysed in $4 \mathrm{~N}-\mathrm{HCl}$ for $12 \mathrm{hr}$ at $100^{\circ}$ in sealed tubes. After evaporating to dryness, samples were redissolved in distilled water and the amino sugar content determined as described by Cessi \& Piliego (1960).

Chromatography. The identification of sugars was achieved by one-dimensional chromatography on paper (Whatman No. 3) using a single-phase solvent $n$-butanol + acetic acid + water $(12+3+5$, by vol.). Sugars were detected by dipping in benzidine + trichloroacetic acid reagent (Smith, 1960) and heating to $100^{\circ}$.

\section{(b) Nitrogen analyses}

Total nitrogen was determined by the micro-Kjeldahl method of Chibnall, Rees \& Williams (1943). Protein nitrogen values were obtained by subtraction of the amino sugar nitrogen content, determined separately, from total nitrogen. For amino acid analysis, samples $\left(5 \mathrm{mg}\right.$.) were hydrolysed at $100^{\circ}$ with $6 \mathrm{~N}-\mathrm{HCl}(0.5 \mathrm{ml}$.) for $\mathrm{I} 8 \mathrm{hr}$. The hydrolysates were evaporated to dryness and redissolved in $0.1 \mathrm{~N}-\mathrm{HCl}$, before analysis. Quantitative amino acid analysis was done by ion-exchange chromatography according to Moore, Spackman \& Stein (1958) using a Technicon Amino Acid Autoanalyser.

\section{(c) Lipids}

Cell walls were extracted first with neutral chloroform + methanol $(2+\mathrm{I}, \mathrm{v} / \mathrm{v})$ and then with acidic $(\mathrm{I} \% \mathrm{HCl})$ chloroform and methanol. All extractions were made on fresh cell wall material under nitrogen at room temperature. Removal of solvents was effected by distillation under reduced pressure. The crude extracts were purified by means of the procedure of Folch, Lees \& Sloane-Stanley (1957). Fatty acid methyl esters were prepared from cell wall lipids as described by Stoffel, Chu \& Ahrrens (1959). Standard reference fatty acid methyl esters were prepared by the more rapid esterification procedure with diazomethane. Analysis of the methyl esters was done using a column packed with acid and alkali washed Celite ' 545 ' (I00-120 mesh, B.D.H. Ltd.) as solid support and $5 \%$ polyethylene glycol adipate as a stationary liquid. The analyses were carried out on a Pye-Argon gas chromatograph. 


\section{(d) Phosphorus}

Samples (I mg.) were boiled with $5 \mathrm{~N}-\mathrm{H}_{2} \mathrm{SO}_{4}$ in a micro-Kjeldahl digestion apparatus. Phosphorus estimations were done on the hydrolysates by the micro-method of Dryer, Tammes \& Routh (1957).

\section{RESULTS}

Cell walls constituted 10.5 and $10.3 \%$ of the dry weight of the deficient and normal yeasts respectively. Treatment with ethylenediamine yielded three fractions, A, B and $\mathrm{C}$, from both types of cell wall (Table I). The corresponding fractions of normal and deficient walls were indistinguishable on the basis of macroscopic appearance. In agreement with the findings of Korn \& Northcote (I960) for bakers' yeast cell walls, phase-contrast microscopy revealed that fraction $\mathbf{C}$ of normal and deficient walls retained the shape of the original cell wall.

Table I. Fractionation of cell walls with ethylenediamine

Fractions A, B and C were isolated after incubation of cell walls with ethylenediamine for three days at $37^{\circ}$. Yields in g./IO0 g. cell walls.

$\begin{array}{ccccc}\text { Fraction } & \overbrace{\text { In water }} & \begin{array}{c}\text { In ethylene- } \\ \text { diamine }\end{array} & \overbrace{\begin{array}{c}\text { Normal } \\ \text { cell walls }\end{array}}^{\text {Sield }} & \begin{array}{r}\text { Deficient } \\ \text { cell walls }\end{array} \\ \text { A } & + & + & 23 \cdot 7 & 23 \cdot 4 \\ \text { B } & - & + & 10 \cdot 4 & 13 \cdot 4 \\ \text { C } & - & - & 59 \cdot 9 & 52 \cdot 5\end{array}$

Table 2. Carbohydrate content of cell walls and fractions

Total hexose was estimated by the anthrone method, glucose by glucose oxidase. The values for mannose were obtained by difference as described under Methods. Hexosamine was estimated by the method of Cessi \& Piliego (1960). Values are expressed in g./100 g. sample.

\begin{tabular}{|c|c|c|c|c|c|c|c|c|}
\hline Total hexose & $59 \cdot 0$ & $56 \cdot 7$ & $69 \cdot 9$ & 84.0 & $75 \cdot 7$ & $70 \cdot 3$ & $69 \cdot I$ & $63 \cdot 3$ \\
\hline Glucose & 0.0 & 0.0 & $14 \cdot 7$ & $76 \cdot 4$ & $57 \cdot 4$ & $68 \cdot 5$ & $37 \cdot 5$ & $47 \cdot 9$ \\
\hline Mannose & $59^{\circ} 0$ & $56 \cdot 7$ & $55 \cdot 2$ & $7 \cdot 6$ & $18 \cdot 3$ & $1 \cdot 8$ & $31 \cdot 6$ & 15.4 \\
\hline Hexosamine & 0.4 & 0.7 & $<0 . \mathrm{I}$ & I. 4 & $1 \cdot 0$ & $7 \cdot 2$ & 0.7 & $4 \cdot 2$ \\
\hline
\end{tabular}

\section{Carbohydrate composition of cell walls and fractions}

Chromatographic analysis of the hydrolysates of normal and of deficient cell wall fractions showed that mannose was the only hexose present in fractions A whereas both mannose and glucose were detected in fractions B and C.

The results of quantitative analysis of carbohydrates are shown in Table 2. The mannose content of normal and deficient fractions A was very similar. Deficient fractions $\mathrm{B}$ and $\mathrm{C}$, however, contained less mannose, but more glucose than the corresponding normal fractions. Overall, the total hexose content of deficient cell walls was only slightly less than that of normal walls. The values obtained in the 
present study for the mannose and glucose content of normal cell walls agree well with those obtained by Northcote \& Horne (1952) for bakers' yeast cell walls. Unfractionated deficient cell walls contained very much more amino sugar than normal cell walls. This fact is reflected in the amino sugar content of deficient cell wall fractions all of which contained more hexosamine than the corresponding normal fractions.

Table 3. The protein content of cell walls and fractions

The values given represent (total nitrogen-hexosamine nitrogen) $\times 6 \cdot 25$. Values are expressed in g. protein/100 g. sample. Total nitrogen was estimated by the micro-Kjeldahl procedure.

$\begin{array}{lcc} & \text { Normal } & \text { Deficient } \\ \text { Fraction A } & 30 \cdot 4 & 29 \cdot 6 \\ \text { Fraction B } & 31 \cdot 2 & 6 \cdot 8 \\ \text { Fraction C } & 8 \cdot 9 & 5 \cdot 9 \\ \text { Unfractionated cell walls } & 15 \cdot 9 & \text { II } \cdot \text { I }\end{array}$

Table 4. The amino acid composition of cell wall proteins

Values in $\mu \mathrm{mole} / 100 \mathrm{mg}$. cell wall protein.

\begin{tabular}{|c|c|c|}
\hline & $\begin{array}{l}\text { Normal } \\
\text { cell walls }\end{array}$ & $\begin{array}{l}\text { Deficient } \\
\text { cell walls }\end{array}$ \\
\hline Aspartic acid & $52 \cdot 5$ & $80 \cdot 8$ \\
\hline Threonine & 105.8 & $166 \cdot 3$ \\
\hline Serine & 110.4 & $151 \cdot 8$ \\
\hline Glutamic acid & $56 \cdot 4$ & $93 \cdot 8$ \\
\hline Proline & $37 \cdot I$ & $56 \cdot 0$ \\
\hline Glycine & $44 \cdot 8$ & $62 \cdot 0$ \\
\hline Alanine & 84.6 & $115 \cdot 3$ \\
\hline Valine & $55 \cdot 6$ & 59.6 \\
\hline Cystine & $2 \cdot 5$ & $\mathrm{I} \cdot 7$ \\
\hline Methionine & $2 \cdot 6$ & Trace \\
\hline iso-Leucine & $40 \cdot 0$ & $39 \cdot 8$ \\
\hline Leucine & $47 \cdot 9$ & $37 \cdot 8$ \\
\hline Tyrosine & $14 \cdot 5$ & I $4 \cdot I^{\prime}$ \\
\hline Phenylalanine & $20 \cdot 7$ & $22 \cdot 2$ \\
\hline Lysine & $44 \cdot 3$ & $39 \cdot 8$ \\
\hline Histidine & $18 \cdot 4$ & $8 \cdot 6$ \\
\hline Arginine & $15 \cdot 8$ & $9 \cdot 6$ \\
\hline Ammonia & $63 \cdot 9$ & $79 \cdot 3$ \\
\hline
\end{tabular}

The protein content of cell walls and fractions

Deficient cell walls and fractions all contained less protein than the corresponding normal materials (Table 3 ). This overall decrease was most marked in the case of deficient fraction B which contained $24.4 \%$ less protein than normal fraction B.

Quantitative amino acid analysis (Table 4) revealed striking differences in the protein composition of normal and deficient cell walls. Thus, the deficient cell wall protein was much richer in threonine, serine, glutamic and aspartic acids, alanine, glycine and proline, but contained less lysine, histidine, and arginine than normal cell wall protein.

Lipid analyses

Normal and deficient cell walls contained the same percentage of lipid. The fatty acids present in normal and in deficient cell wall lipids were predominantly unsaturated 
(Table 5). The major components palmitoleic and oleic acids comprised approximately the same percentage of the fatty acids of normal and deficient cell walls.

\section{Phosphorus content of cell walls and fractions}

The phosphorus content of the deficient cell wall and of each of the deficient cell wall fractions was less than that of the normal materials (Table 6).

Table 5. Identity and percentage composition of fatty acids from cell wall lipids

Analyses were carried out at $175^{\circ}$ on a $5 \%$ polyethylene glycol adipate column. Gas flow $45 \mathrm{ml}$./min. Pressure $15 \mathrm{lb}$./ $\mathrm{in}^{2}$.

\begin{tabular}{|c|c|c|c|}
\hline \multicolumn{2}{|c|}{ Identity of fatty acid } & \multicolumn{2}{|c|}{ Total fatty acid (\%) } \\
\hline $\begin{array}{l}\text { Shorthand } \\
\text { designation }\end{array}$ & $\begin{array}{l}\text { Familiar } \\
\text { name }\end{array}$ & $\begin{array}{l}\text { Normal } \\
\text { lipid }\end{array}$ & $\begin{array}{l}\text { Deficient } \\
\text { lipid }\end{array}$ \\
\hline I 2:0 & Lauric & 0.4 & 0.6 \\
\hline 13:0 & - & 0.5 & 0.3 \\
\hline \multicolumn{2}{|c|}{ Unidentified } & 0.3 & $0 \cdot 3$ \\
\hline $14: 0$ & Myristic & 0.7 & $1 \cdot 2$ \\
\hline \multicolumn{2}{|c|}{ Unidentified } & 0.7 & $2 \cdot I$ \\
\hline $15: 0$ & - & Trace & Trace \\
\hline \multicolumn{2}{|c|}{${ }^{15: 0}$ Unidentified } & 0.2 & 0.3 \\
\hline I6:0 & Palmitic & $16 \cdot 7$ & $14: 4$ \\
\hline $16: 1$ & Palmitoleic & $42 \cdot 4$ & $42 \cdot I$ \\
\hline I8:0 & Stearic & $4 \cdot 3$ & 4.9 \\
\hline I 8: I & Oleic & $33 \cdot 7$ & $33 \cdot 8$ \\
\hline
\end{tabular}

Table 6. The phosphorus content of cell walls and fractions

Values in $\mu \mathrm{g} . / \mathrm{mg}$. sample.

$\begin{array}{lcc} & \text { Normal } & \text { Deficient } \\ \text { Fraction A } & 7 \cdot 4 & 6 \cdot \mathbf{6} \\ \text { Fraction B } & 3 \cdot 2 & 2 \cdot 0 \\ \text { Fraction C } & \mathbf{1} \cdot 4 & \mathbf{1} \cdot \mathbf{1} \\ \text { Unfractionated cell walls } & 3 \cdot 8 & \mathbf{2 \cdot 7}\end{array}$

\section{DISCUSSION}

Growth of Saccharomyces cerevisiae w.s. in media without inositol resulted in the formation of an aberrant cell wall which contained less mannose but more glucose than normal cell walls. This finding is consistent with the suggestion (Chung \& Nickerson, 1954) that inositol is required for the interconversion of mannose and glucose phosphates which are important intermediates in the biosynthesis of mannan and glucan from glucose. Gosh, Charalampous, Sison \& Borer (I960) reported that a strain of $S$. carlsbergensis when grown in inositol-deficient media formed an abnormal cell wall containing greatly increased amounts of glucan. However, no significant change in mannan content occurred with this yeast.

Inositol-deficiency results in a large increase in the whole cell lipid content of Saccharomyces cerevisiae w.s. (Challinor \& Daniels, 1955). It is surprising, therefore, that the content and fatty acid composition of the normal and deficient cell wall lipids were found to be so similar. 
The cell wall of inositol-deficient yeast contained less protein than the normal cell wall. Furthermore, determination of the amino acids present showed that deficient cell wall protein was quite different in composition. Kessler \& Nickerson (I959) proposed that combination between the two moieties of polysaccharide-protein complexes is effected by esterification involving the carbonyl groups of the protein and the hydroxyl groups of the polysaccharide. Thus, the large increase in concentration of aspartic and glutamic acids in deficient yeast cell wall protein possibly reflects an essential requirement for these amino acids to maintain the integrity of the cell wall. Glucosamine may play a part in binding polysaccharide-protein complexes in the yeast cell wall (Eddy, 1958; Korn \& Northcote, 1960). In the present study, a large increase in hexosamine was found in the deficient cell wall, and it is possible that this increase compensates in part for the relatively low content of the basic amino acids lysine, histidine and arginine. Eddy \& Williamson (1959) showed that yeast protoplasts could give rise to a superficial membrane which somewhat resembled the intact cell wall but which contained $\mathrm{N}$-acetyl glucosamine as the principal nitrogenous material rather than amino acid residues.

The electron micrographs of several workers including Northcote \& Horne (1952), Agar \& Douglas (1955) and Bartholomew \& Levin (I955), suggest that the yeast cell wall is a layered structure. Although the chemical composition of the individual layers is unknown, mannan occupies a large proportion of the surface of the wall (Eddy, I958). The work of Millbank \& Macrae (I964) supports the view that the mannanprotein complex overlays the glucan. Thus, it is reasonable to assume that fractions $A$ isolated here with ethylenediamine represent part of the surface of the intact cell wall. The marked similarity in composition between normal and deficient fractions $A$ probably reflects therefore an attempt on the part of the deficient cell to maintain the surface regions of the wall intact under adverse growth conditions. It is generally agreed that the mannan and protein components of the cell fabric are intimately associated. The ratio of mannose to protein found here is constant (approx. 2) for the normal cell wall and each of the fractions $\mathrm{A}, \mathrm{B}$ and $\mathrm{C}$ isolated from it. However, only $\mathrm{A}$ of the deficient wall fractions showed a mannose to protein ratio of 2. This observation underlines the similarity between normal and deficient fractions $A$.

On the other hand, deficient fractions $\mathrm{B}$ and $\mathrm{C}$ are very different in composition from corresponding normal cell wall fractions. Large decreases in the mannose and protein content of these fractions are accompanied by equally marked increases in glucose and hexosamine. There is no doubt that such changes result in a much weakened cell wall as indicated by the relative ease of rupture of the deficient cell. However, a complete interpretation of these findings must await a more precise knowledge of the structure of the normal cell wall.

\section{REFERENCES}

Agar, H. D. \& Douglas, H. C. (I955). Studies of budding and cell wall structure of yeast-electron microscopy of thin sections. J. Bact. 70, 427 .

BARTholomew, J. W. \& Levin, R. (I955). The structure of Saccharomyces carlsbergensis and $S$. cerevisiae as determined by ultra-thin sectioning methods and electron microscopy. J. gen. Microbiol. 12, 473 .

Cessi, C. \& Piliego, F. (1960). Determination of aminosugars in presence of amino acids and glucose Biochem. J. 77, 508.

Challinor, S. W. \& Daniels, N. W. R. (1955). Fat production by inositol-deficient yeast. Nature, Lond. 176, I 267. 
Challinor, S. W., Daniels, N. W. R. \& Hall, J. C. (1958). Recent studies in yeast and their significance in industry. Soc. Chem. Indust. Mon. No. 3 .

Challinor, S. W., Power, D. M. \& Tonge, R. J. (1964). Effects of inositol-deficiency on yeast, with particular reference to chemical composition of the cell and of the cell wall. Nature, Lond. 203, 250.

Chibnall, A. C., Rees, M. W. \& Williams, E. F. (1943). The total nitrogen content of egg albumin and other proteins. Biochem.J. 37, 354.

Chung, W. \& Nickerson, W. J. (1954). Polysaccharide synthesis in growing yeasts. J. biol. Chem. 208, 395 .

Dryer, R. L., TAmmes, A. R. \& Routh, J. I. (1957). The determination of phosphorus and phosphatase with N-phenyl-p-phenylene diamine. J. biol. Chem. 225, 177.

EdDy, A. A. (1958). The structure of the yeast cell wall. II. Degradative studies with enzymes. Proc. Roy. Soc. B 149, 435.

EdDY, A. A. \& Williamson, D. H. (1959). Formation of aberrant cell walls and of spores by the growing yeast protoplast. Nature, Lond. 183, I IOI.

Emery, W. B., MCLeod, N. \& RoBinson, F. A. (1946). Comparative microbiological assays of members of the vitamin B complex in yeast and liver extracts. Biochem. J. 40, 426.

FALCONE, G. \& Nickerson, W. J. (1956). Cell wall mannan-protein of baker's yeast. Science N.Y. 124, 272.

FolCh, J., Lees, M. \& Sloane-Stanley, G. H. (1957). A simple method for the isolation and purification of total lipids from animal tissues. J. biol. Chem. 226, 497.

Gosh, A., Charalampous, F. C., Sison, Y. \& Borer, R. (1960). Metabolic functions of myo-inositol. I. Cytological and chemical alterations in yeast resulting from inositol deficiency. J. biol. Chem. 235, 2522.

HouwINK, A. L. \& KREGer, D. R. (1953). Cell wall of yeasts-electron microscope and X-ray diffraction. Antonie van Leeuwenhoek $\mathbf{1 9}$, I.

KeSSLER, G. \& NiCKerSON, W. J. (I959). Glucomannan-protein complexes from cell walls of yeasts. J. biol. Chem. 234, 228I.

KoRN, E. C. \& NoRTHCOTE, D. H. (1960). Physical and chemical properties of polysaccharides and glycoproteins of the yeast cell wall. Biochem. J. 75, 12.

Millbank, J. W. \& Macrae, R. M. (1964). Degradation of yeast cell wall by fractionated snail-gut enzyme. Nature, Lond. 201, 1347.

MOORE, S., SPACKMAN, D. H. \& STEIN, W. H. (1958). Chromatography of amino acids on sulphonated polystyrene resins. Analyt. Chem. 30, 1185.

NoRThCOTE, D. H. \& HoRNE, R. W. (1952). The chemical composition and structure of the yeast cell wall. Biochem. J. 5I, 232.

Roklofsen, P. A. (1953). Yeast mannan, a cell wall constituent of bakers' yeast. Biochim. biophys. Acta 10, 477 .

Roelofsen, P. A. \& Hoette, I. (1951). Chitin in the cell wall of yeasts. Antonie van Leeuwenhoek I7, 297.

Sмтtн, I. (1960). Chromatographic and Electrophoretic Techniques, 2nd Ed., by I. Smith. London: William Heinemann.

Stoffel, W., Chu, F. \& Ahrrens, E. H. (1959). Analysis of long-chain fatty acids by gas-liquid chromatography-micromethod for preparation of methyl esters. Analyt. Chem. 3I, 307. 